\title{
THE ANATOMY OF THE PROSOBRANCH TRICHOTROPIS BOREALIS BRODERIP \& SOWERBY, AND THE SYSTEMATIC POSITION OF THE CAPULIDAE
}

\author{
By Alastair Graham, D.Sc. \\ The Department of Zoology, University of Reading \\ (Text-figs. I-4)
}

The anatomy of some members of the family Calyptraeidae has been adequately described by previous workers (Kleinsteuber, I913; Giese, I915; Moritz, 1938), and a considerable amount of information has been published on the feeding and the unusual reproductive activities of Crepidula (Orton, I912; Coe, I944). Of the anatomy and way of living of the members of those other families of gastropods (Trichotropidae and Capulidae) that Thiele (1929) has united with the calyptraeids in his Stirps Calyptraeacea, much less is known. Orton (I912) and Yonge (1938) have described the feeding mechanism of Capulus ungaricus; and the anatomy of Thyca, a parasitic member of the same family, has been briefly described by Koehler \& Vaney (I9I2). Nothing seems to be known of the anatomy or way of life of members of the Trichotropidae. Yet an investigation of some of these points seems overdue in the light of Lebour's discovery (1937) that Capulus passes through an echinospira larval stage. This stage does not occur in other members of the Calyptraeacea, although present in two other groups of the mesogastropods, the Lamellariacea and the Cypraeacea. The idea at once presents itself that the capulids may perhaps be more accurately classified as members of one or other of these two groups rather than as members of the Calyptraeacea. The work recorded in the following pages was directed towards answering this question, and would suggest that the original classification is the more correct.

The names used are those of Winckworth (1932).

\section{ANATOMICAL OBSERVATIONS}

\section{Trichotropis borealis Broderip \& Sowerby}

The family Trichotropidae, of which Trichotropis borealis is the sole British representative, is on the whole confined to colder seas. In Britain $T$. borealis is restricted to the northernmost parts of England and to Scotland, and is not littoral. The animals used in this work were collected off Oban by Dr V. Fretter of Birkbeck College, University of London, and it is to her kindness and to that 
of Mr T. G. W. Fowler, on whose boat she was working, that I owe the opportunity of examining them. They were found at a depth of 2-3 fathoms on clinker cast overboard from the fire grates of the West Highland boats. The material was fixed in Bouin and proved very difficult to section: I am indebted to $\mathrm{Mr} \mathrm{C}$. Best of the Otological Research Unit of the Medical Research Council at the National Hospital for Nervous Diseases, London, for a magnificent series of celloidin sections cut $\mathrm{IO} \mu$ thick.

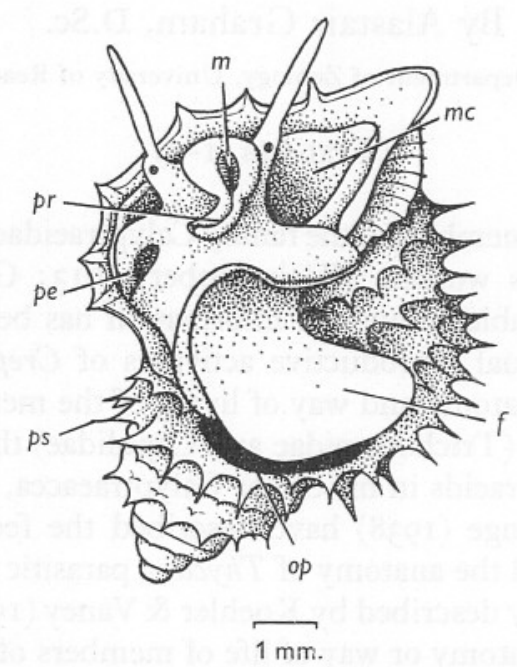

Fig. I. Trichotropis borealis, drawn from a living specimen. $f$, foot; $m$, mouth; $m c$, opening to mantle cavity; $o p$, operculum; $p e$, penis recurving into mantle cavity; $p r$, proboscis curving from mouth to right side of foot; $p s$, periostracal spines on shell.

In respect of its external features $T$. borealis presents the usual appearance of a small prosobranch with spirally coiled shell (Fig. I). The shell itself is well covered with thick periostracum which is drawn into numerous pointed processes $(p s)$ set especially along the lines of the spiral ridges running round the whorls. When the head and the foot are extended, it may be seen that the tentacles are long and slender, with the eyes placed about one-quarter of their length from the base. The foot $(f)$ is rather abruptly cut off both in front and in the rear with a slight narrowing in the middle, but it is mobile and there does not appear to be any specialization of its anterior end, except for a degree of elongation. The posterior end carries a horny operculum $(o p)$. The opening into the mantle cavity $(m c)$ is large and the edge of the mantle skirt is plain and does not appear to contain marginal glands apart from those concerned with the secretion of the shell. The only other point in the external characteristics of the mollusc is the presence of a short proboscis extending forwards from the mouth ( $p r)$. Like that of Capulus, this proboscis is grooved on the upper side to produce a channel which runs from the tip of the proboscis 
along its length to the mouth $(m)$ at its base. In normal circumstances the proboscis is kept with its tip turned towards the animal's right so that it lies dorsal to the front end of the foot and rests along the right side of that organ. A similar curvature was noted in respect of the proboscis of Capulus by Orton (I9I2) but denied by Yonge (I938). The surface of the proboscis is not ciliated except on the floor of the groove, and the structure in Trichotropis seems to function in the same way as the corresponding organ in Capulus. When the process of feeding is investigated by means of carmine powder suspended in sea water it is found that a strong current enters the mantle cavity on the animal's left, that particles from this fall on to and travel across the floor of the mantle cavity and are then carried along the right side of the head and foot, as in Capulus. In this way they reach the tip of the proboscis, travel up its groove and at the base of this are licked into the buccal cavity by means of the radula.

Small specimens of Trichotropis possess a penis (pe), a slightly flattened finger-shaped structure grooved on the lateral side and normally lying recurved in the mantle cavity. It is a solid organ without detectable blood spaces and there are no glands on its surface. From its base the seminal groove may be traced to the genital aperture, an elongated slit lying on the right side of the mantle skirt. Larger specimens lack the penis and are female, so that the animals seem to be successive hermaphrodites and protandrous.

The mouth leads to the buccal cavity, within which lies the buccal mass carrying the radula and strengthened by a pair of cartilages, and into which a pair of salivary glands discharges by very short ducts. The glands are small lobed pouches and manufacture a secretion of almost pure mucus, the epithelium lining the walls being composed of mucous cells alternating with slender supporting cells which are sometimes ciliated. The surface of the buccal cavity is covered with cuticle in most areas, but there is no well developed jaw. The oesophagus is long, running back to the stomach in the visceral hump. The glands of the mid-oesophagus are well developed and the morphologically ventral part of this section of the oesophagus has walls flung into a series of obliquely directed lamellae. The longitudinal dorsal folds, which separate the dorsal food channel from the glands, are long, project deeply into the lumen of the oesophagus and are wrapped one over the other so as to isolate the two parts of the oesophagus more or less completely from each other. The posterior oesophagus is, as is usual in prosobranchs, a simple tube with a ciliated columnar epithelium containing mucous glands.

It leads to the stomach, a not very capacious cavity lying directly underneath the mantle on the outer side of the visceral hump. The oesophageal opening and that of the style sac lie almost side by side at its lower end, and two wide ducts from the digestive gland open to the stomach close to the same point. From one of these the major typhlosole emerges and runs along the style sac; the minor typhlosole, which in the style sac forms the other 
boundary of the intestinal groove, dies away on the stomach wall between the two apertures of the digestive gland. A considerable area (perhaps most) of the rest of the stomach wall is covered with cuticle which is raised slightly at one point to form the gastric shield. The epithelium which lines the stomach is tall and columnar, either ciliated or bearing the cuticle; apart from this it is rather featureless. In the style sac there appears the characteristic ciliated epithelium of this part of the molluscan stomach-low columnar cells, with homogeneous cytoplasm and large nuclei, bearing many cilia-with taller, narrower cells and mucous cells in the typhlosoles. No crystalline style is apparent, nor, in view of the existence of well-developed oesophageal glands, is it likely that one exists (Graham, I939).

The digestive gland occupies the outer half of the more apical whorls of the visceral hump. Its tubules contain two types of cells, one much more abundant than the other, and clearly responsible for most of the digestive activity of the gland. I am not certain what is the function of the other type,

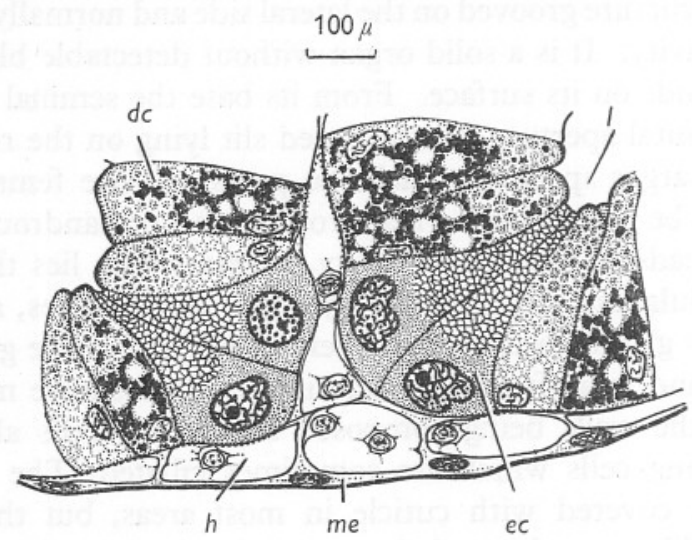

Fig. 2. Trichotropis borealis. Part of section across digestive gland. $d c$, digestive cell; $e c$, excretory cell; $h$, interlobular haemocoelic space; $l$, lumen of tubule; me, epithelium of mantle.

since I have not had enough animals to allow observation in different physiological states or to permit experiment. The first type, the digestive cell (Fig. 2, $d c$ ), is a tall club-shaped cell with an inconspicuous nucleus lodged in the narrow base and swelling to a tumid apex bulging into the cavity of the tubule. There are clear signs in the material that this type of cell takes particles of food into food vacuoles for an intracellular digestive process, and I suspect that the distal end of the cell is nipped off with zymogen granules at another stage of the cycle of activity.

The second type of cell $(e c)$ is much less abundant and is located in crypts in the tubules especially on the sides which face the mantle (me). Its shape is more or less triangular in section with the base broad and a narrow apex 
reaching to the lumen of the tubule $(l)$. The cytoplasm is not vacuolated, except slightly so near the apex; at the base it is dense and stains rather darkly with iron haematoxylin. The outstanding feature of the cell is the nucleus, which is large, lobed, and contains a prominent nucleolus and numerous granules of chromatin. All these features suggest a high level of metabolic activity, and the broad base which the cell presents to the haemocoelic spaces $(h)$ between neighbouring tubules of the gland would indicate that the cell is responsible for some process which involves the transfer of material from blood to cell or vice versa. In other gastropods (see below) this type of cell is often concerned with excretion, and this may be true in Trichotropis too, but I have insufficient evidence on the point.

The intestine starts at the distal end of the style sac and runs across the body from left to right to open at the anus, which is situated a little way in from the mouth of the mantle cavity. The whole length is ciliated and glandular with a thin layer of muscle external to the epithelium. Near the stomach the wall is particularly rich in mucous cells and these again become abundant near the anus; in the intervening length of intestine, however, mucous cells are scarce and the glands appear to be manufacturing some type of protein secretion since they stain intensely with such stains as iron haematoxylin. The lips of the anus, which is placed on a short papilla, are drawn out into a filament of some length hanging freely into the pallial cavity.

The faecal pellets are well compacted, short, oval bodies containing sand grains, diatom cases, sponge spicules and vegetable debris-the typical faecal contents of a detritus feeder.

In the nervous system of Trichotropis borealis the cerebral ganglia lie close together above the oesophagus and posterior to the salivary glands. Behind them and below are the pleural ganglia, so closely associated with the cerebrals as to form a single dumbbell-shaped mass of nervous tissue on each side. The pedal ganglia with their associated statocysts, however, lie well forward and ventrally so that the cerebropedal and pleuropedal connectives are relatively lengthy. The supra-oesophageal and suboesophageal ganglia lie close to the oesophagus, the former a little posterior to the nerve ring, the latter directly under the right pleural ganglion. It has, in fact, established a zygoneurous connexion with this which is absent on the other side of the body. No dialyneury exists on either side. The visceral ganglia lie ventrally in the visceral hump, both to the left side of the mid-line, one close to the kidney, which it innervates along with the reproductive apparatus, the other near the pericardial wall, to which it sends branches as well as supplying the stomach and the digestive gland.

The osphradium, ctenidium and hypobranchial gland are all well developed structures within the mantle cavity. The osphradium is a bipectinate structure as in many prosobranchs. The gill lies along, rather than across, the mantle 
cavity, and the filaments are like those of Capulus as described by Yonge (1938). The hypobranchial gland is extensive and rich in secreting cells, of which there appear to be three different sorts, intermingled with ciliated cells. The last are excessively slender cells with wedge-shaped distal ends squashed between the bulging gland cells. Most of the gland cells secrete mucus, but there are also two kinds secreting material which is not of that nature. Mucous cells also occur on the gill filaments and abound on the floor of the mantle cavity so that vast quantities of that substance are available for the trapping of food particles and for their transport to the proboscis. The mantle skirt and the internal parts of the body are largely occupied by a coarsely reticulate connective tissue.

The gonad, a testis in young animals and an ovary in older ones, occupies half of the upper whorls of the visceral hump, lying on the concave inner side of the spiral. It is divided into lobes which converge on a gonadial duct which takes a convoluted path down the visceral hump to the renal and pallial sections of the reproductive tract (Fretter, 1946). In the male phase this section is used as a seminal vesicle and is occupied by masses of mature sperm, unorientated. It is not muscular and is lined by a squamous epithelium which is not ciliated.

Near the ventral end of the visceral hump the gonadial duct joins the renal section of the genital tract, a narrow tube with a ciliated cubical epithelium and some muscle fibres in the walls. It has no pericardial connexion. The renal vas deferens ends by opening into the pallial section, which, even in the male phase, is already showing the rudiments of the female accessory glands, and which may, perhaps, have some prostatic function. The male duct leads on to a ciliated tract which runs along the right (outer) wall of this section. The duct opens to the mantle cavity by a narrow, slit-like aperture and the ciliated tract extends as far as the anterior border of this. For a short distance before it reaches this point, however, it is applied against a similar ciliated tract located on the right body-wall of the snail. Sperm can therefore pass, partly by ciliary action, partly by their own movement, from the genital duct to the seminal groove and so to the penis.

Even in the male phase, as was noted by Giese (1915) in the course of his investigation of the genital tracts of the calyptraeids and of Capulus, the beginnings of the later female system are well developed. In Trichotropis a receptaculum seminis runs dorsally from the point where the renal and pallial sections of the duct join, in the form of a narrow, blind tube, the inner end of which branches to form a tuft of three short tubules. The main part of the pallial section takes the form of a large glandular pouch within which areas may be distinguished as the albumen and capsule glands. The fundamental histological structure of all these regions is the same-excessively tall and narrow supporting cells, often ciliated, being wedged between gland cells, all of which lie within the basement membrane of the epithelium. 
Variation affects only the nature of the secretion elaborated by the glands. In the albumen gland the cells contain spherules which do not stain with iron haematoxylin; while in the capsule gland the granules of secretion usually do take up this stain and there are also, at its inner and outer limits, strips of cells which are exclusively mucous. There is no visible bursa copulatrix, and on copulation it must happen that the penis is inserted directly into the capsule gland.

The oldest animal of which I had sections had still ripe spermatozoa in the spaces of the gonad and in the proximal section of the genital tract, whilst the receptaculum seminis was empty: the animal was therefore still functionally male. Nevertheless, the gonad contained eggs of all sizes, some of which measured $0.3 \mathrm{~mm}$. in diameter and were laden with yolk granules. It appears that this animal was close to the point when change from male to female was imminent, and it would probably have acted as female at the next reproductive phase.

\section{Capulus ungaricus (L.)}

The feeding mechanism of this animal has been described by Orton (I9I2) and Yonge (1938), and the contents of the mantle cavity noted, but otherwise its anatomy is not well known. Capulus is limpet-like in shape, with the shell tip tilted backwards like a Phrygian cap. The shell has a wide and round mouth which cannot be closed by an operculum, and it is covered by a thick, brown, periostracal layer, fringed at the edges but smooth elsewhere. The head is not elongated, bears two short, flattened tentacles with eyes at their bases and also a proboscis like that of Trichotropis but longer, with the mouth at its base and a groove dorsally. As Yonge (1938) notes, it is mobile and not restricted to one position as that of Trichotropis appears to be. The foot is rounded but has a thin anterior part which can be stretched well forward, and it is on to the upper surface of this, as Yonge (1938) has shown, that the food particles from the mantle cavity are led before being licked up by the proboscis. The opening into the mantle cavity is large and the edge of the mantle skirt is simple and devoid of marginal glands apart from the shell gland. The columellar muscle is horseshoe-shaped with the mantle cavity embraced between its two anteriorly directed arms. In this the lobed osphradium and the ctenidium extend obliquely forward from the left arm of the horseshoe, with the space between ctenidium and the right arm of the horseshoe occupied by the hypobranchial gland, the rectum and the reproductive ducts.

The alimentary tract of Capulus is simpler than that of Trichotropis but in general is similar to it: The oesophageal region, as noted earlier (Graham, I939), is devoid of glandular equipment apart from mucous cells, and is a relatively simple tube passing to the stomach. The stomach (Fig. 3) lies in a vertical position on the left side of the visceral hump, its morphologically 
anterior end almost at the apex of the hump, where the oesophageal aperture is placed, whilst the intestine opens from the style sac ventrally. As in Trichotropis, two large ducts lead from the digestive gland, both opening near the point of entry of the oesophagus. From one of these the major typhlosole $\left(t_{1}\right)$ runs to the style sac, the minor typhlosole $\left(t_{2}\right)$ originating on the stomach wall near the oesophageal opening. A gastric shield $(g s)$ lies on the right side of the stomach. From the stomach the intestine $(i)$ runs across to the anus and is flung into a posteriorly directed loop on the way. It is rich in mucous cells, especially near the anus.

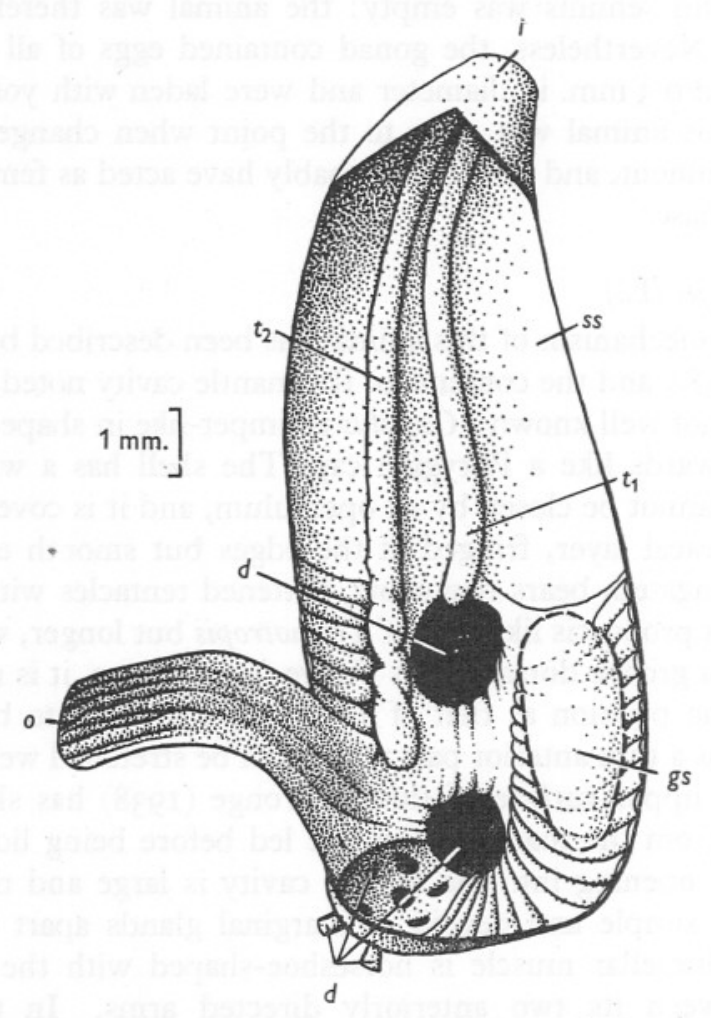

Fig. 3. Capulus ungaricus. Dissection of stomach. $d$, ducts of digestive gland; gs, gastric shield; $i$, intestine; $o$, oesophagus; $s s$, style sac; $t_{1}$, major typhlosole; $t_{2}$, minor typhlosole.

In the digestive gland of Capulus, as in that of Trichotropis, two cell types occur: one digestive, the second with another function. The former is a tall club-shaped cell presenting indications of secretory or phagocytic activity, depending upon the stage in the digestive cycle at which the mollusc has been killed. The second cell is lower, of pyramidal shape, and is tucked into the angles of the tubule with the broad base presented to the intertubular haemocoelic spaces. The cell has dense cytoplasm with a few granules 
embedded in it and a large lobed nucleus. It is difficult, in the absence of experimental results, to be any surer of the action of this type of cell in Capulus than of its homologue in Trichotropis; but the activity is more likely to be secretory or excretory than concerned with the direct manipulation of food particles.

Capulus possesses a nervous system (Fig. $4 A$ ) built upon similar lines to that of Trichotropis, the sole major difference detected between the two being that in addition to the zygoneurous connexion established between the right pleural $(p g)$ and the suboesophageal $(s b g)$ ganglia, there is a dialyneury $(d)$ brought into being by an intermingling of the left pallial nerve $(l p n)$ from the left pleural ganglion with the osphradial nerve (lon) from the supra-oesophageal ganglion $(s p g)$ : this occurs where the two nerves pass alongside one another over the shoulder of the columellar muscle on their way into the mantle skirt. The two visceral ganglia (vg) lie ventrally in the basal part of the visceral hump, as in Trichotropis, though perhaps more closely than in that mollusc.

As is well known, Capulus is a successive hermaphrodite, each animal passing through a young male phase, when it is provided with a penis and the rudiments of the accessory female glands, to reach a definitive female phase when the penis is lost. The general anatomy of the reproductive system has been previously described by Giese (I9I5), and I have nothing significant to add to his account of this system: its most important features are the absence of a gonopericardial duct, the presence of a seminal groove from genital pore to penial apex, the lack of penial glands in the male phase, and the development of an albumen gland and receptaculum seminis at the inner end of the capsule gland in the female stage. The receptaculum has the form of a fingershaped pouch slightly branched at the distal extremity. There is no bursa copulatrix.

\section{Calyptraea sinensis $\mathrm{L}$. and Crepidula fornicata $\mathrm{L}$.}

The anatomy of these animals agrees in all points with that of the calyptraeids described by Kleinsteuber (I913) and Moritz (1938). It need not, therefore, be elaborated; and it will suffice to mention points of difference between the members of this family, the trichotropids and the capulids. While the general body shape is limpet-like, more of the spiral coiling of the visceral hump has been retained in the calyptraeids than in Capulus, although the visceral mass is completely symmetrical in the related genus fanacus (Kleinsteuber, I9I3). The mantle edge, though still smooth, shows more complexity than in the other families: it is bifurcated and folded over the entrance to the mantle cavity so as to form the food pouch described by Orton (I9I2) and by Yonge (1938); it is also more extensive, forming a large shelflike projection round the body of the gastropod. It is no longer simple, but shows a triple folding, the most dorsal part being a simple fold in direct contact with the shell above, lodging the shell gland and covered by an 
unciliated cubical epithelium ventrally. The middle fold, by far the largest of the three, contains blood vessels, two circumpallial nerves and a series of large marginal glands which discharge to the ventral side. This fold of the mantle edge has retractor muscle fibres running into it which originate on the shell, and it is covered laterally and medially by an unciliated cubical epithelium, but on its ventral surface by a ciliated columnar epithelium which is rich in mucous cells. The marginal glands are spherical bodies opening by a long, narrow duct lined by squamous cells. The secreting cells are grouped

A

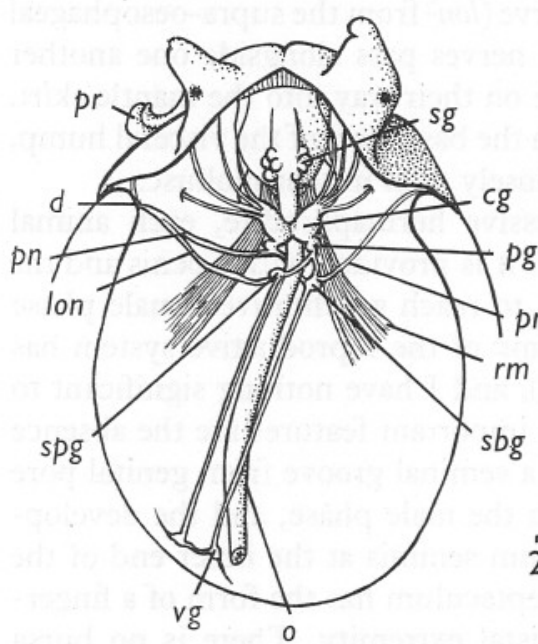

$B$

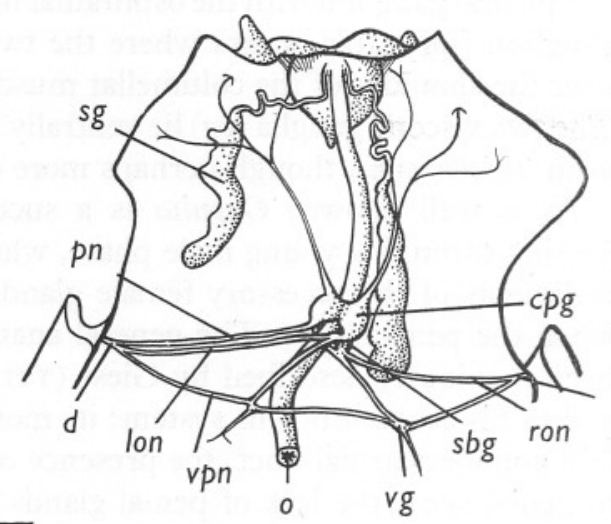

$2 \grave{\mathrm{m} m}$.

Fig. 4. A, dissection to show part of the nervous system of Capulus ungaricus. $B$, dissection to show part of the nervous system of Crepidula fornicata. $c g$, cerebral ganglion; $c p g$, fused cerebral and pleural ganglia; $d$, point of dialyneury; lon, left osphradial nerve from supra-oesophageal ganglion; $o$, oesophagus; $p g$, pleural ganglion; $p n$, pallial nerve from pleural ganglion; $p r$, proboscis; $r m$, retractor muscle of proboscis; ron, right osphradial nerve from suboesophageal ganglion; $s b g$, suboesophageal ganglion; $s g$, salivary glands; $s p g$, supra-oesophageal ganglion; $v g$, visceral ganglion; $v p n$, pallial nerve from visceral ganglion.

to form the spherical body and are filled with dense cytoplasm. The nature of the secretion is unknown, but it seems to be secreted on noxious stimulation and the glands are therefore repugnatorial. The third fold of the mantle edge is a small one constricted off the medial edge of the second. This triple subdivision of the pallial edge is, as already noted by Odhner (1932), characteristic of the archaeogastropod and bivalve mantle and would seem to be primitive.

The head of a calyptraeid has been elongated in what may be spoken of as the 'neck' region, that is behind the tentacles and penis, and is there provided with a pair of lateral extensions, the cephalic lappets. Their development is 
associated with the ciliary food-collecting mechanism of these animals. In relation to that, too, the mantle cavity extends far up the visceral hump on the left side, forcing the shell muscles to lie on the right and preventing them from forming a horseshoe as in Capulus. The length of the gill filaments, as described by Orton (I9I2) and Yonge (1938), has also increased in this connexion and the ctenidial axis (Graham, I939) has been converted into what Orton (I9I3) described as an 'endostyle'-an accessory gland producing mucus for the trapping of the food particles. The osphradium is small and pectinate; the hypobranchial gland is well developed.

The alimentary canal (Graham, I939) is simple. In the buccal cavity the radula is weak and rests on a small buccal mass. The salivary glands (Fig. $4 B$, $s g$ ) are larger structures than in either trichotropids or capulids. They are tubular, reaching posteriorly from the buccal cavity as far as the level of the nerve ring, the anterior third of this length being occupied by a narrow duct, the rest by gland. In the glandular section three types of cell occur: narrow, ciliated cells squashed between gland cells of two sorts, the more numerous secreting a substance which is not mucus, the second type secreting mucus. There are no oesophageal glands and the stomach contains a crystalline style. The oesophagus enters it at its posterior end and the intestine, which leaves the style sac anteriorly, has a figure-of-eight loop on its course to the anus. The digestive gland contains two types of cell, one digestive and the other excretory. This second type invariably has large vacuoles in the cytoplasm in which lie concretions, often yellow in colour and partly crystalline in nature, though in other individuals the vacuoles may be filled with many minute granules. Since these concretions may also be seen in the faeces, and since the cells in which they lie have broad bases facing the blood spaces in and around the digestive gland, it seems safe to suggest that they consist of waste material. Nothing comparable may be detected in the other cells of the digestive gland, although it is into these that experimentally introduced foods find their way. The excretory matter in the other cells appears therefore to be endogenous rather than faecal in nature. It is possible that no secretion of digestive enzymes takes place from the gland.

The excretory organ is clearly composed of a nephridial gland in close relationship to the pericardial cavity and a large nephridial sac discharging to the mantle cavity.

The nerve ring lies at the posterior end of the 'neck' and therefore some way behind the buccal mass. The dorsal ganglia - an apparently single pairare formed from fusion of the cerebrals and pleurals, the boundaries between the two being obliterated (Fig. $4 B, c p g$ ). On the right side the supra-oesophageal ganglion lies contiguous to the right pleural, of which it simply appears to be a lobe, whilst the suboesophageal $(s b g)$ lies similarly ventrally. Still more ventrally are placed the pedal ganglia. A zygoneury has therefore been established on the right side, and since fusion occurs on the left (near the point 
where the nerves pass to the mantle skirt) between the osphradial nerve from the supra-oesophageal ganglion (lon), the pallial nerve from the left pleural ganglion $(p n)$ and a pallial nerve from the visceral $(v p n)$ and, similarly, on the right between osphradial nerves from the suboesophageal ganglion (ron) and a pallial branch from the right visceral, there is a very complete link up in the nervous system. The two visceral ganglia $(v g)$ lie only a short distance posterior to the nerve ring and also rather far apart, so that the visceral loop has a triangular shape with the base between the two visceral ganglia.

The general plan of the reproductive system of calyptraeids has been described by Giese (I9I5), and I have nothing to add. The animals are protandrous hermaphrodites, the duct has a gonopericardial canal and the penis has glands at its base and apex.

\section{Discussion}

When the anatomical points described above are taken into consideration, it seems that all three families of gastropods may fairly be thought to possess a high degree of similarity of structure.

The shell in at least two of the three families shows a thick periostracal layer which tends to be drawn out into processes. In accord with their mobility the trichotropids preserve the spirally wound visceral hump and shell of the typical prosobranch. They may gather food with their proboscis as well as collect it out of the water current maintained through the mantle cavity. With greater dependence on this current as a source of food less mobility is required and the limpet-like shape of Capulus and the calyptraeids is adopted, although that has been achieved in different ways in these two groups, the mantle cavity being elongated in a transverse direction in the capulids (which allows the formation of a horseshoe-shaped columellar muscle) and in a longitudinal direction in the calyptraeids. The evolution of repugnatorial glands is presumably related to the lack of operculum and the immobility of the animals. A similar evolution attends the alimentary tract: Trichotropis has an oesophagus which shows the usual prosobranch structure and the animal has no crystalline style. In the calyptraeids there has been developed the style, presumably as a ready source of enzyme in connexion with the microphagous habit; and it seems likely that Capulus has evolved in the same way. The oesophageal glands, as is usual in such cases, are lost and the radular apparatus reduced, though there is increasing complexity in the mantle cavity as that part of the body evolves in efficiency as a food collecting apparatus. The fundamental organization of the stomach, with intestinal and oesophageal apertures at opposite ends, two large openings to the digestive glands close to the oesophageal aperture and no spiral caecum, appears similar in all, as does the structure of the gland itself with two contrasting types of cell. In each of the types the intestine runs across from left to right to the anus and is flung into a backwardly directed loop on the way. 
In all three groups the nervous system is modified in identical fashion and the only significant difference is in the varying shape of the visceral loop: this is long in Trichotropis, moderately long in Capulus and distinctly short and triangular in the calyptraeids. But that is, in fact, the kind of change in shape which would accompany a change from the normal prosobranch appearance to the limpet facies and probably has no deeper significance.

The reproductive system is a further example of agreement. All the animals are hermaphrodite; all have the rudiments of the female organs present in the young, male, phase; and all have a seminal groove leading forwards to and along a slender penis which disappears when the animal becomes female. The plan of the glands in the female phase is similar in all three. It seems to be only in Crepidula that this special timing of reproductive activity has become the basis of special behavioural patterns.

In their reproduction, too, there seems to be a certain degree of similarity. All appear to lay their eggs in capsules (Thorson, I935; Lebour, I937) which may be fastened to bivalve shells (Trichotropis), or to stones or shells; they are often incubated by the parent (Calyptraea, Crepidula, Capulus). All, however, differ in the stage at which the young animals escape. In Crepidula the eggs give rise to free-swimming veliger larvae; in Capulus to free-swimming echinospira larvae; whereas in both Calyptraea and Trichotropis the veliger is suppressed and the young hatch as crawling miniatures of their parents.

The echinospira larva occurs also in Lamellariacea and in Cypraeacea. To what extent do the members of these groups resemble the Calyptraeacea anatomically? Their anatomical characters have been described by Vayssière (I923), Thiele (I929), Rau (I934) and Fretter (I946, I95I) and may be summarized in the following paragraphs.

There is little tendency for the production of periostracum around the shells of these animals; instead, another tendency becomes obvious-for the mantle to grow over the shell and ultimately enclose it completely. The mantle edge has no special marginal glands but is extended into a respiratory siphon.

The animals are all macrophagous carnivores, provided with jaws and proboscis for the manipulation of their prey, which tends to be predominantly sessile tunicates and coelenterates-as must, inevitably, be the case when such a slow-moving animal as a gastropod mollusc turns carnivore (Graham, I953). The alimentary canal is well provided with extensive oesophageal glands (Amaudrut, I898; Fretter, I95I) and the stomach is on the whole simpler than that of the calyptraeacean, as might be expected in view of their food (Graham, I949).

The foot (Fretter, I95I) is provided with a posterior mucous gland in addition to the ordinary anterior one and in that respect differs from the foot of the calyptraeacean, although there is a tendency in all three groups to lose the operculum. The explanation of the loss is, however, clearly different in 
the two cases: in the one it is part of the trend towards a limpet-like way of living; in the others it is part of the trend towards an internal shell.

Other general resemblances between the two groups of gastropods become obvious when their nervous and reproductive systems are compared. In the former there is a considerable degree of concentration, bilateral zygoneury occurring in both Lamellariacea and Cypraeacea and the pleural ganglia being closely adpressed to the cerebrals. In the reproductive system the sexes are separate in Lamellariacea and Cypraeacea and there is no bursa copulatrix in the female. In Simnia an open seminal groove runs from the male pore to the penis, but in Trivia and Erato and in the Lamellariacea the entire male duct is closed except for an accessory opening, perhaps of the nature of a safety valve, which puts the prostate into communication with the mantle cavity. The egg-cases are of relatively delicate construction since they are (in those species that have been observed) given protection by being sunk into the tissues of the ascidians upon which the adult animals normally feed; from them free-swimming echinospira larvae are produced (Lebour, 1935). Simnia, though clearly a member of the Cypraeacea in all other respects, is anomalous in its reproductive behaviour since the capsules which it produces are attached to its food on the surface (colonies of Alcyonium or Eunicella) and the larvae which emerge from them are ordinary veligers.

The picture of an idealized and generalized member of the Cypraeacea or Lamellariacea which emerges from this brief list of their outstanding characters is, clearly, of an animal distinctly different from that of the calyptraeacean. There is, without doubt, a much greater degree of relationship between Capulus and the other members of the Calyptraeacea than between it and the members of either the Lamellariacea or Cypraeacea. The echinospira larva is not a stage upon the presence or absence of which weighty arguments can rest: the Cypraeacea and Lamellariacea are akin without appeal to their common possession of that type of larva. Simnia is undoubtedly a cypraeacean even though it lacks an echinospira, and Capulus is equally a calyptraeacean even though it does possess one.

If this relationship be granted it is also true that the Cypraeacea, the Lamellariacea and the Calyptraeacea may all be regarded as lying close together in the great galaxy of the mesogastropods, and one obvious indication of this is the occurrence of the echinospira larva in all. Its presence, however, should not be taken to indicate more than that.

\section{SUMMARY}

The anatomy of Trichotropis borealis is described. The salient points are the possession of a spirally coiled shell with an operculum and a suboral proboscis, grooved dorsally, which curves to the right side of the head and collects food particles obtained from the water current in the mantle cavity. The alimentary 
canal has small salivary glands and reduced jaws, but well developed glands in the mid-oesophagus and no crystalline style. The stomach is relatively simple with two large ducts opening from the digestive gland. Two main types of cell occur in this gland, one digestive in function, the other believed to be excretory. In the nervous system the cerebral and pleural ganglia are united, the supra- and suboesophageal ganglia have migrated well forwards and a zygoneury and a left dialyneury both occur. The animals are successive hermaphrodites and are protandrous. In the male phase a grooved penis occurs connected by a seminal groove with the genital pore in the mantle cavity. Rudiments of female organs are already present at this stage and later form a capsule gland with an albumen gland and receptaculum seminis. No bursa copulatrix occurs in the female and the penis disappears.

In Capulus ungaricus the animal has become limpet-like with a round shell and no operculum. Oesophageal glands have been lost but otherwise the gut and other soft parts conform to the same pattern as those of Trichotropis. Of Crepidula fornicata and Calyptraea sinensis the same may be said. Fusion in the nervous system is more extensive and feeding is carried out entirely by ciliary means; there is no proboscis.

Capulus possesses an echinospira larval stage. Comparison of its anatomy with that of members of the Lamellariacea and Cypraeacea, which (Simnia apart) also possess such a larva, shows that it is nearer to the other members of the Calyptraeacea. Possession of the echinospira, therefore, suggests a general relationship of these three superfamilies rather than a closer relationship of Capulus to the Lamellariacea and Cypraeacea than to the Calyptraeacea.

\section{REFERENCES}

AmAudRut, A., I898. La partie antérieure du tube digestif et la torsion chez les mollusques gastéropodes. Ann. Sci. nat. (zool.), Sér. 8, T. 7, pp. I-29I.

CoE, W. R., I944. Sexual differentiation in mollusks. II. Gastropods, amphineurians, scaphopods, and cephalopods. Quart. Rev. Biol., Vol. I9, pp. 85-97.

FretTER, V., I946. The genital ducts of Theodoxus, Lamellaria and Trivia, and a discussion on their evolution in the prosobranchs. F. Mar. biol. Ass. U.K., Vol. 26, pp. 312-5I.

- 195I. Some observations on the British cypraeids. Proc. malac. Soc. Lond., Vol. 29, pp. I4-20.

GIESE, M., I915. Der Genitalapparat von Calyptraea sinensis Linn., Crepidula unguiformis Lam. und Capulus hungaricus Lam. Z. wiss. Zool., Bd. II4, pp. I69-23I.

GrAHAM, A., I939. On the structure of the alimentary canal of style-bearing prosobranchs. Proc. zool. Soc. Lond., B, Vol. I09, pp. 75-II2.

— 1949. The molluscan stomach. Trans. roy. Soc. Edinb., Vol. 6I, pp. 737-78.

- 1953. Introduction to a symposium on Form and Function in the Mollusca. Proc. Linn. Soc., Lond., Session I64, 1951-52, pp. 213-17.

Kleinsteuber, H., I9I3. Die Anatomie von Trochita, Calyptraea und fanacus. Zool. Fb., Suppl. Bd. I3, Fauna Chilensis, Bd. 4, pp. 385-476. 
Koehler, R. \& VAney, C., I9I2. Nouvelles formes de gastéropodes ectoparasites. Bull. sci. Fr. Belg., T. 46, pp. I9I-2I7.

Lebour, M. V., I935. The echinospira larvae (Molluscs) of Plymouth. Proc. zool. Soc. Lond., pp. 163-74.

1937. The eggs and larvae of the British prosobranchs with special reference to those living in the plankton. F. Mar. biol. Ass. U.K., Vol. 22, pp. 105-66.

Moritz, C. E., I938. The anatomy of the gasteropod Crepidula adunca Sowerby. Univ. Calif. Publ. Zool., Vol. 43, pp. 83-92.

OdHner, N. H., I932. Zur Morphologie und Systematik der Fissurelliden. Fena. Z. Naturw., Bd. 67, pp. 292-309.

Orton, J. H., I9I2. The mode of feeding of Crepidula, with an account of the current producing mechanism in the mantle cavity, and some remarks on the mode of feeding in gastropods and lamellibranchs. F. Mar. biol. Ass. U.K., Vol. 9, pp. $444-78$.

__ I9I3. On ciliary mechanisms in brachiopods and some polychaetes, with a comparison of the ciliary mechanisms on the gills of molluscs, Protochordata, brachiopods and cryptocephalous polychaetes, and an account of the endostyle of Crepidula and its allies. F. Mar. biol. Ass. U.K., Vol. Io, pp. 283-3Ir.

RAU, A., 1934. Anatomisch-histologische Untersuchungen an Cypræen. Fena. Z. Naturw., Bd. 69, pp. 83-I68.

ThIELE, J., I929. Handbuch der systematischen Weichtierkunde. I. Teil. Jena: Fischer.

Thorson, G., I935. Studies on the egg-capsules and development of arctic marine prosobranchs. Medd. Gronland, Bd. I00, no. 5, pp. I-7I.

VAYSSIÈRE, A., I923. Recherches zoologiques et anatomiques sur les mollusques de la famille des Cypraeidés. Ire partie. Ann. Mus. Hist. nat. Marseille, T. I8, pp. I-I2O.

WincKWorth, R., I932. The British marine Mollusca. F. Conch., Vol. I9, pp. 2 I I-52.

YoNGE, C. M., I938. Evolution of ciliary feeding in the Prosobranchia, with an account of feeding in Capulus ungaricus. F. Mar. biol. Ass. U.K., Vol. 22, pp. $453-68$. 